\title{
The use of gaming technologies in foreign language classes as a way to prevent and correct language anxiety
}

\author{
Galina V. Sorokoumova ${ }^{1 *}$, Olga V. Shurygina ${ }^{1}$, Tatyana E. Egorova ${ }^{2}$, Irina V. Burova ${ }^{1}$, \\ and Yulia Y. Pospelova ${ }^{1}$ \\ ${ }^{1}$ Linguistics University of Nizhny Novgorod, Department of Methods of Teaching Foreign \\ Languages, Pedagogy and Psychology, Nizhny Novgorod, Russia \\ ${ }^{2}$ Nizhny Novgorod Institute of Management - Branch of Russian Presidential Academy of National \\ Economy and Public Administration under the President of Russia (RF), Department of Philosophy, \\ Sociology and Management Psychology, Nizhny Novgorod, Russia
}

\begin{abstract}
The paper looks into the problem of finding methods and educational technologies that reveal the creative potential of students, ensure their involvement in the educational process, and ensure the prevention and correction of psychological problems the students might have. The authors review the value of gaming technologies, the peculiarities of their use in teaching foreign languages, especially in connection with the emergence of language anxiety of students, and analyze the types of language anxiety and the role of gaming technologies in the prevention and correction of language anxiety of students. The paper focuses on the causes of language anxiety in teenage students. The study aimed to look into the influence of game forms of education on the reduction of language anxiety of school students learning foreign languages. To achieve the goal and confirm the hypothesis put forward, the authors used the method of measuring language anxiety during the study of a foreign language by Horwitz (Foreign Language Classroom Anxiety Scale). At the formative stage, a set of games was developed, which was used in German lessons with students of the experimental group for one month. Further, the paper analyzes the results of the study of the influence of game forms of learning on the reduction of language anxiety in the study of foreign languages. The paper has not only theoretical significance in terms of considering language anxiety, but also practical significance and novelty because the results of the study showed the high efficiency of gaming technologies and confirmed the fundamental possibility of prevention and psychocorrection of language anxiety with their help.

Keywords: gaming technologies, language anxiety, prevention and correction of language anxiety, language and speech games.
\end{abstract}

\footnotetext{
*Corresponding author: galsors@mail.ru
} 


\section{Introduction}

One of the priority tasks of modern Russian education is the search for "new methods of teaching and upbringing, as well as educational technologies that reveal the creative potential of students, ensuring the development of all basic skills and abilities, as well as increasing their motivation for learning and involvement in the educational process" [1]. Psychological and pedagogical theory and practice recognize the value of gaming technologies in the process of education, upbringing [2], the development of all the necessary skills of the 21 st century in students [3], in the development of the cognitive sphere [4], personal qualities [5, $6]$, in prevention and correction of various psychological problems.

\section{$2 \quad$ Literature review}

The process of learning a foreign language is a complex process that depends on various factors and conditions. There are psychological problems that negatively affect students' involvement in the educational process, their motivation to learn a foreign language, working efficiency, and, as a result, academic performance.

One of the most common problems is language anxiety, which is expressed in fear due to the need to put into practice one's own foreign language skills. For the first time, the concept of language anxiety was mentioned in the studies of E. Horwitz [7: 167].

In psychological and pedagogical research, three types of language anxiety are distinguished:

- communicative anxiety, which appears in case of need to communicate with someone in a foreign language. Students with a high level of communicative anxiety tend to misunderstand the statements of their classmates, at the same time, their statements also do not find understanding in the classroom [8];

- anxiety associated with the performance of review assignments, tests, or checking the skills of students can occur both before and after the test. Describing this type of anxiety as "test anxiety", Hans Morschitzky believes that it is a reaction to a subjective feeling of threat, which arises in situations of control of academic performance or achievement of certain results. According to studies, up to $30 \%$ of German students tend to experience anxiety and fear caused by various kinds of tests [9];

- anxiety which is associated with the fear of condemnation, negative opinion, expectation of negative evaluation [8].

This problem is especially acute in the teenage years, as a negative evaluation of one's skills and abilities acquired at this age, especially from peers, can stay with the teenager for a long time and cause the formation of a negative attitude towards the subject as a whole. According to the research of I.E. Abramova, O. M. Sherekhova, E.P. Shimolina, conducted in groups of students studying a foreign language, $47 \%$ of the subjects answered that language anxiety began to form in secondary school, due to incorrect correction of errors and an unfriendly reaction from the teacher [10].

According to A.A. Serdyuk, A.O. Taskanov, E.A. Stukolov, referring to A.S. Batinova, anxiety and fear of criticism among students very often arise because school students do not interact much with their classmates, mainly working in the "student/teacher" format [11].

Various factors can serve as the sources of language anxiety in teenagers learning a foreign language, such as an unfavorable atmosphere in the classroom, high requirements imposed by their teacher, personal characteristics of students. Researchers emphasize that language anxiety is cyclical, i.e. making mistakes in oral speech, students become more anxious, which provokes the emergence of new mistakes, and, to maintain a positive impression of themselves, students with high levels of anxiety tend to avoid oral responses in the future. Therefore, in the absence of corrective measures, language anxiety can worsen, 
influencing not only the student's attitude to classes but also to the language itself, its speakers, their culture, and the country of the target language.

In this regard, psychologists and teachers agree on the need to use various methods and means of preventing and correcting language anxiety in students.

To solve the problem of language anxiety in foreign language classes A. A. Serdyuk, A. O. Taskanova, E.A. Stukolova suggest working in groups where students can repeatedly include language material in their statements, combining new material with what they have learned earlier. Students show independence by expressing agreement or disagreement, correcting each other's mistakes. Among the effective methods of group work, the authors distinguish debate, interrogation, and the method of clusters [11].

As noted by A.V. Bortnikova, the advantage of using game forms in foreign language classes is explained by the fact that games help to activate the skill of quickly finding lexical units, solving communication problems, developing the tempo of speech, increasing selfesteem, self-confidence, and the ability to express one's thoughts. Often in the process of games, students have to overcome difficulties, which gives them pleasure, because work on linguistic and speech difficulties in foreign language lessons in the process of playing turns into an interesting cognitive activity [12].

Vietnamese researcher Trang Thi Tran views the control of language anxiety in foreign language classes as the most effective method for its correction and prevention. The researcher concludes that by controlling and realizing the manifestations of language anxiety and the reasons for its occurrence in the classroom in a foreign language, students manage to reduce the degree of its impact [13]. At the same time, a significant role is also assigned to teachers who create favorable conditions for expression and stimulate the oral answers of students in foreign language classes [13]. Game forms of education are an effective method of preventing and reducing language anxiety in teenage students [14]. Games not only have a teaching function, but also promote cohesion and, as a result, develop communication skills [15]. Gaming technologies are just the tool that contributes to the communicative activity nature of learning, involvement, activation of students' speech activity in a foreign language, reduction of emotional tension, and correction of language anxiety.

\section{$3 \quad$ Methods}

To confirm the hypothesis about the influence of game forms of learning on the reduction of language anxiety in the study of foreign languages, we conducted a study, which was carried out at grammar school No. 1 with an in-depth study of the German language in 5a grade. The average age of students was 12 years. Our study was conducted in 3 stages.

At the ascertaining stage, we formed two groups: the experimental group (EG) and the control group (CG) with 15 students in each, where we carried out the diagnostics of language anxiety. For diagnostics, we used the method of measuring language anxiety when studying a foreign language developed by Horwitz (Foreign Language Classroom Anxiety Scale or FLCAS). This technique allows us to study the general level of language anxiety in students, as well as to identify the manifestation of language anxiety in three aspects: fear of failure in interpersonal communication, test anxiety, and fear of negative evaluation.

At the second formative stage, we developed a set of games that were used in German lessons with students of the EG for one month. When choosing games for classes, we followed several criteria: the game had to be feasible for each student; the game had to be focused on solving educational and communication problems; the game had to reveal the degree of formation of certain language, speech skills, and abilities;

Our complex included "Icebreaker" game techniques to relieve emotional stress at the beginning of the lesson; language games aimed at the development of phonetic, grammatical, and lexical skills (tongue twisters, proverbs, solving crosswords, dominoes, contests, and 
quizzes) and speech games for teaching reading, speaking and listening (paraphrasing, restoring what was missed in the text, role-playing games, the "snowball", creative tasks), involving individual, frontal and group forms of work with students.

At the control stage, we re-diagnosed the level of students' language anxiety and compared the results of the ascertaining and control stages. To prove the reliability of the data, we used the nonparametric Mann-Whitney test.

\section{$4 \quad$ Results}

Table 1 shows the indicators of language anxiety among students of the experimental sample from the EG $(\mathrm{n} 1=15)$ and $C G(\mathrm{n} 2=15)$ before and after the study.

Table 1. Indicators of language anxiety in students from the EG $(n 1=15)$ and $C G(n 2=15)$ before and after the study.

\begin{tabular}{|c|c|c|c|c|}
\hline \multirow{2}{*}{$\begin{array}{c}\text { The general level of } \\
\text { language anxiety }\end{array}$} & \multicolumn{2}{|c|}{$\begin{array}{c}\text { Results before the experiment } \\
\text { (people/ \%) }\end{array}$} & \multicolumn{2}{|c|}{$\begin{array}{c}\text { Results after the experiment } \\
\text { (people/ \%) }\end{array}$} \\
\cline { 2 - 5 } & EG & CG & EG & CG \\
\hline High & $4(33 \%)$ & $5(33 \%)$ & 1 & 5 \\
\hline Average & $9(53 \%)$ & $8(40 \%)$ & 11 & 9 \\
\hline Low & $2(24 \%)$ & $3(20 \%)$ & 3 & 2 \\
\hline
\end{tabular}

\section{Discussion}

As the results presented in Table 1, show, students from both the EG and the CG had approximately the same level of language anxiety. We can see indicators of low, medium, and high levels of language anxiety. After the formative stage, the number of students from the EG with a high level of language anxiety (at the level of reliability $p<0.01$ ) significantly decreased. There were no significant changes in the CG.

Analyzing certain aspects of language anxiety in teenagers, it is worth noting that fear of negative evaluation and interpersonal communication dominates in foreign language classes, which is due to the specifics of the age when communicating with peers and their evaluation have a significant impact on self-esteem and self-attitude of a teenager.

The indicators of individual aspects of language anxiety in the EG before and after the experiment are shown below.

Table 2. Indicators of language anxiety among students in the EG before and after the experiment.

\begin{tabular}{|c|c|c|}
\hline \multirow{2}{*}{$\begin{array}{c}\text { Indicators of individual aspects of language } \\
\text { anxiety }\end{array}$} & \multicolumn{2}{|c|}{$\begin{array}{c}\text { Results of the EG } \\
\text { (average score for the group) }\end{array}$} \\
\cline { 2 - 3 } & $\begin{array}{c}\text { Before the } \\
\text { experiment }\end{array}$ & $\begin{array}{c}\text { After the } \\
\text { experiment }\end{array}$ \\
\hline $\begin{array}{c}\text { Fear of negative evaluation } \\
\text { Fear of interpersonal communication in a foreign } \\
\text { language }\end{array}$ & 3.3 & 3.0 \\
\hline Fear of test tasks & 3.2 & 2.9 \\
\hline
\end{tabular}

After participating in the formative program, students from the EG were diagnosed (at the level of statistical significance $\mathrm{p}<0.001$ ) with a decrease in all indicators of language anxiety. 


\section{References}

1. Natsionalnyi proekt "Obrazovanie" ["Education" national project] (2019). Accessed on: July 20, 2020. [Online]. Available:

https://strategy24.ru/rf/education/projects/natsionalnyy-proekt-obrazovanie

2. G.V. Sorokoumova, Ispolzovanie sovremennykh aktivnykh metodov obucheniya na zanyatiyakh po psikhologicheskim distsiplinam [The use of modern active teaching methods in psychology classes], in Sovremennaya obrazovatelnaya sreda: teoriya i praktika: materialy Mezhdunarodnoi nauchno-prakticheskoi konferentsii [Modern educational environment: theory and practice. Materials of an International research and practice conference], 71-79 (TsNS Interaktiv plyus, Cheboksary, 2018)

3. G.V. Sorokoumova, Psikhologicheskiy trening kak effektivnyy metod razvitiya navykov, neobkhodimykh $v 21$ veke [Psychological training as an effective method of developing skills needed in the 21st century], in L.A. Abramova (Ed.), Razvitie nauki i obrazovaniya [Development of science and education], 115-122 (Publishing House Sreda, Cheboksary, 2018)

4. O.S. Gazman, Neklassicheskoe vospitanie: ot avtoritarnoi pedagogiki k pedagogike svobody [Non-classical education: from authoritarian pedagogy to the pedagogy of freedom] (MIROS, Moscow, 2002)

5. I.V. Patrusheva, Psikhologiya i pedagogika igry [Psychology and pedagogy of play], (Yurait, Moscow, 2020)

6. D.I. Ershov, Mir Nauki, Kultury, Obrazovaniya, 6(79), 57-61 (2019). https://doi.org/10.24411/1991-5497-2019-10025

7. E.N. Yakovleva-Yurchak, Problemy yazykovoi trevozhnosti uchashchikhsya, izuchayushchikh inostrannye yazyki i puti ee preodoleniya [Problems of language anxiety in students of foreign languages and ways to overcome it], in Sovremennoe obrazovanie: aktualnye voprosy, dostizheniya i innovatsii: sbornik statei XV Mezhdunarodnoi nauchno-prakticheskoi konferentsii [Modern education: topical issues, achievements and innovations: a collection of papers of the XV International research and practice conference], 166-168 (Nauka i Prosveshchenie, Penza, 2018). Accessed on: November 09, 2020. [Online]. Available: https://www.elibrary.ru/item.asp?id=32669924

8. S. Elaldi, Educational Research and Reviews, 11(6), 219-228 (2016). https://doi.org/10.5897/ERR2015.2507

9. H. Morschitzky, Prüfungen meistern - Ängste überwinden, 167 (Verlag Fischer Gann, Munderfing, 2016)

10. I.E. Abramova, O.M. Sherekhova, E.P. Shimolina, Vestnik Kostromskogo Gosudarstvennogo Universiteta, 22(3), 168-171 (2016). Accessed on: November 11, 2020. [Online]. Available: https://www.elibrary.ru/item.asp?id=27033527

11. A.A. Sredyuk, A.O. Taskanova, E.A. Stukolova, Vestnik Saratovskogo Oblastnogo Instituta Razvitiya, 2(22), 76-80 (2020). Accessed on: November 25, 2020. [Online]. Available: https://www.elibrary.ru/item.asp?id=43984732

12. A.V. Bortnikova, Innovatsionnost i multikompetentnost v prepodavanii i izuchenii inostrannykh yazykov: sbornik nauchnykh trudov [Innovation and multi-competence in teaching and learning foreign languages: a collection of research papers], 351-359 (Rossiiskii Universitet Druzhby Narodov, Moscow, 2016). Accessed on: November 28, 2020. [Online]. Available: https://www.elibrary.ru/item.asp?id=26520178 
13. T.T.T. Tran, K. Moni, Cogent Education, 2(1), 992593 (2015). https://doi.org/10.1080/2331186X.2014.992593

14. F. Alrabai, Innovation in Language Learning and Teaching, 9(2), 163-190 (2015). https://doi.org/10.1080/17501229.2014.890203

15. O.I. Vaganova, E.A. Aleshugina, Scientific Vector of the Balkans, 4(2(8)), 21-24 (2020). https://doi.org/10.34671/SCH.SVB.2020.0402.0006 